\title{
A ideia de Equilíbrio Político de Benjamin Constant no Constitucionalismo Brasileiro: Poder Judiciário como novo Poder Moderador?
}

\author{
Benjamin Constant's ideia of Political \\ Equilibrium in Brazilian Constitutionalism: \\ Judiciary as the new Moderating Power? \\ La idea del Equilibrio Político de Benjamin \\ Constant en el Constitucionalismo Brasileño: \\ el Poder Judicial como nuevo Poder \\ Moderador?
}

Martonio Mont'Alverne Barreto Lima* Ítalo Reis Gonçalves**

\begin{abstract}
1 Introdução. 2 A ideia de equilíbrio político de Benjamin Constant no constitucionalismo brasileiro. 2.1 O quinto poder de Benjamin Constant (ou o Poder Real). 2.2 O quarto poder da Constituição Imperial de 1824 (ou o Poder Moderador). 3 Poder judiciário como novo Poder Moderador. $3.1 \mathrm{O}$ ativismo judicial e a judicialização da política no Brasil redemocratizado. 3.2 O quarto poder da Constituição Federal de 1988 (ou o poder análogo). 4 Conclusão. Referências.
\end{abstract}

\section{RESUMO}

Objetivo: Partindo da hipótese de que, no Brasil redemocratizado, o Poder Judiciário desempenha função análoga à do Poder Moderador da Constituição Imperial de 1824 e

\footnotetext{
" Professor Titular da Universidade de Fortaleza (UNIFOR) (Fortaleza, CE, Brasil). Doutor em Direito pela Joahann Wolfgang Goethe-Universität/Frankfurt am Main (Alemanha). Procurador do Município de Fortaleza. E-mail: <barreto@unifor.br>. https://orcid.org/0000-0003-0052-2901

"Mestrando em Direito Constitucional Público e Teoria Política pela Universidade de Fortaleza. Advogado. Fortaleza - CE - BR. E-mail: <italoreisgoncalves@gmail.com>. https://orcid.org/00000002-0566-3415
} 
promove acúmulo de poder e desequilíbrio político, o artigo busca apresentar criticamente alguns dos principais postulados da teoria constitucional de limitação de poder de Benjamin Constant e, com base nesta, investigar a atuação jurídico-política dos juízes e tribunais nacionais (em especial, do Supremo Tribunal Federal), que desempenham papel fundamental na dinâmica democrática do País.

Metodologia: Adota-se, quanto à natureza, metodologia aplicada, pois pretende oferecer respostas práticas sobre a jurisdição constitucional no Brasil; quanto ao objetivo, metodologia explicativa, pois pretende delimitar a relação entre a teoria de Benjamin Constant e a judicialização da política, assim como identificar algumas das principais consequências desse fenômeno para a democracia nacional; quanto à abordagem do problema, metodologia qualitativa, pois pretende analisar e interpretar a expansão funcional dos juízes e tribunais sobre controvérsias políticas e morais sem limitá-la a elementos numéricos específicos. Através principalmente de revisão bibliográfica, investigação legislativa e análise de casos, desenvolve-se pesquisa verticalizada sobre a temática proposta.

Resultados: Conclui-se que a ideia de manutenção de equilíbrio político através da atuação majoritária de juízes e tribunais, novos pretensos agentes externos, neutros e reativos, viabiliza que o Poder Judiciário ultrapasse as suas amarras constitucionais e decida qualquer controvérsia política ilimitadamente, usurpando a soberania popular e fragilizando o pacto democrático estabelecido pela Constituição Federal de 1988. A solução para o desequilíbrio político não reside na autoridade de um agente político superior; mas sim na ativa atuação política popular e efetivação do sistema de freios e contrapesos.

Contribuições: $\bigcirc$ artigo, através de análise histórico-política das bases teóricas do constitucionalismo nacional, elucida alguns dos mais relevantes pontos da teoria de Benjamin Constant e de como esta foi recepcionada pelo constitucionalismo nacional e ainda oferece algumas possíveis explanações sobre a judicialização da política brasileira e a sua influência sobre o delineamento jurídico-político do Brasil redemocratizado.

Palavras-chave: Poder Judiciário. Poder Moderador. Benjamin Constant. Equilíbrio político. Judicialização da política.

\section{ABSTRACT}

Objective: Based on the hypothesis that, in re-democratized Brazil, the Judiciary is analogous to the Moderating Power of the Imperial Constitution of 1824 and promotes accumulation of power and political disequilibrium, this paper aims to critically present some of the main postulates of Benjamin Constant's constitutional theory of power 
A ideia de equilíbrio político de Benjamin Constant no Constitucionalismo Brasileiro: Poder Judiciário como novo poder moderador?

limitation and, based on this, to investigate the legal-political performance of national judges and courts, which play a fundamental role in Brazilian democratic dynamics.

Methodology: The nature of the adoped methodology is applied, as it intends to offer practical answers on the constitutional jurisdiction in Brazil; explanatory, as it intends to delimit the relationship between Benjamin Constant's theory and the judicialization of politics, as well as to identify some of the main consequences of this phenomenon for national democracy; qualitative, as it intends to analyze and interpret the functional expansion of judges and courts on political and moral controversies without limiting it to specific numerical elements. Through mainly bibliographic review, legislative investigation and case analysis, vertical research on the proposed theme is developed.

Results: This paper concludes that the idea of political equilibrium through the majority action of judges and courts, the new alleged external, neutral and reactive agents, enables the Judiciary to overcome its constitutional bonds and decide any political controversy in an unlimited way, usurping popular sovereignty and weakening the democratic pact established by the Federal Constitution of 1988. The solution to the political disequilibrium does not lie in the authority of a superior political agent, but in active popular political action and compliance with the system of checks and balances.

Contributions: This paper, through historical-political analysis of the theoretical bases of national constitutionalism, elucidates some of the most relevant points of Benjamin Constant's theory and how it was received by national constitutionalism and still offers some possible explanations about Brazilian judicialization of politics and its influence for the legal-political design of a re-democratized Brazil.

Keywords: Judiciary Power. Moderating Power. Benjamin Constant. Political equilibrium. Judicialization of politics.

\section{RESUMEN}

Objetivo: Partiendo de la hipótesis de que, en el Brasil redemocratizado, el Poder Judicial cumple una función similar a la del Poder Moderador de la Constitución Imperial de 1824 y promueve la acumulación de poder y el desequilibrio político, el artículo busca presentar críticamente algunos de los principales postulados de la teoría constitucional de la limitación del poder de Benjamin Constant y, con base en ello, investigar el desempeño jurídico-político de los jueces y tribunales nacionales, que realizan un papel fundamental en la dinámica democrática del país.

Metodología: El artículo adopta la metodología aplicada, ya que pretende ofrecer respuestas prácticas sobre la jurisdicción constitucional en Brasil; explicativa, ya que pretende delimitar la relación entre la teoría de Benjamin Constant y la judicialización 
de la política, así como identificar algunas de las principales consecuencias de este fenómeno para la democracia nacional; cualitativa, ya que pretende analizar e interpretar la expansión funcional de jueces y tribunales sobre controversias políticas y morales sin limitarla a elementos numéricos específicos. A través principalmente de revisión bibliográfica, investigación legislativa y análisis de casos, se desarrolla una investigación vertical sobre el tema propuesto.

Resultados: El artículo concluye que la idea del equilibrio político a través de los jueces y tribunales, los nuevos presuntos agentes externos, neutrales y reactivos, permite al Poder Judicial superar sus lazos constitucionales y decidir cualquier controversia política ilimitadamente, usurpando la soberanía popular y debilitando el pacto democrático establecido por la Constitución Federal de 1988. La solución al desequilibrio político no reside en la autoridad de un agente político superior, pero em la acción política popular activa de conformidad con el sistema de controles y equilibrios.

Contribuciones: El artículo, a través del análisis histórico-político de las bases teóricas del constitucionalismo nacional, dilucida algunos de los puntos más relevantes de la teoría de Benjamin Constant y cómo fue recibida por el constitucionalismo nacional y aún ofrece algunas posibles explicaciones sobre la judicialización de la política brasileña y la su influencia para el desarrollo jurídico-político del Brasil redemocratizado.

Palabras-chave: Poder Judicial. Poder Moderador. Benjamin Constant. Equilibrio político. Judicialización de la política.

\section{INTRODUÇÃO}

O Brasil, país multifacetado em parte por ter sido consideravelmente influenciado por forças estrangeiras ao longo da sua formação e do seu desenvolvimento, apresenta uma complexa identidade jurídico-política. A análise e a compreensão das bases do constitucionalismo brasileiro são imprescindíveis para o desvendamento e a resolução das mais relevantes controvérsias que pairam sobre o atual panorama nacional. Sem a adequada compreensão do passado, é inviável a percepção do presente e fadada ao fracasso a construção do futuro. Por isso, regredir ao início do século XIX, época-chave para a definição da identidade constitucional pátria, faz-se necessário para responder ao seguinte questionamento, que é o ponto de partida deste artigo: no século XXI, o Poder Judiciário desempenha função análoga à do Poder Moderador?

Talvez a principal influência para a concepção e o desenvolvimento de um projeto constitucional brasileiro tenha sido Benjamin Constant (1767-1830), autor liberal suíço 
A ideia de equilíbrio político de Benjamin Constant no Constitucionalismo Brasileiro: Poder Judiciário como novo poder moderador?

que propôs uma teoria constitucional de limitação de poder. Contrapondo-se às ideias de soberania de Hobbes (1588-1679) e Rousseau (1712-1778), Constant defendia que o poder soberano, ainda que existente, não era ilimitado, sendo a sua contenção por meio do Poder Real - concentrado em e exercido pelo monarca, agente externo, neutro e reativo - essencial para a manutenção do equilíbrio político e consequente formação de uma sociedade justa e próspera.

Da teoria de Constant surgiram as sementes constitucionais brasileiras que germinaram e transformaram-se na Constituição Imperial de 1824. Esse documento, que buscou, prioritariamente, manter o equilíbrio político e consolidar a unidade nacional de um Brasil ainda em formação, instaurou o Poder Moderador: capacidade de mediar os conflitos entre os três outros poderes (Executivo, Legislativo e Judiciário), concentrada em e exercida pelo imperador, agente pretensamente externo, neutro e reativo. Contudo, principalmente em razão de uma importação descontextualizada dos postulados de Constant, a instituição do Poder Moderador possibilitou que o imperador aparelhasse o sistema político brasileiro e utilizasse-o não em favor da vontade geral, mas sim da vontade real, desempenhando um papel parcial, ativo e despótico - contrário ao previsto por Constant - e promovendo o desequilíbrio político. $\mathrm{O}$ imperador absoluto, falsamente limitado pelas amarras constitucionais, na realidade, concentrava e exercia um poder materialmente ilimitado. A partir da ideia de manutenção do equilíbrio político por meio da atuação de um agente supostamente externo, neutro e reativo, o Poder Moderador, concebido como a chave de toda a organização política, tornou-se o principal mecanismo de usurpação e perpetuação de poder no Brasil Imperial.

Após a proclamação da República em 1889, o Poder Moderador deixou de existir explícita e formalmente no constitucionalismo brasileiro, mas a sua base ideológica permaneceu ditando os rumos da política nacional. A busca por um agente externo, neutro e reativo capaz de mediar os conflitos entre os Três Poderes e manter o equilíbrio político viabilizou a concentração de poder desproporcional - ainda que não ilimitado, como o do imperador no século XIX - nas mãos de um ou poucos indivíduos de natureza "messiânica" que se valeram do aparelhamento do sistema político pátrio para condicionarem o seu exercício funcional-político a interesses próprios: Getúlio Vargas durante o Estado Novo (1937-1946) e militares durante a Ditadura Militar (1964-1985), por exemplo.

No Brasil redemocratizado (1988-atualidade), a materialização da ruptura com o período ditatorial se deu com a promulgação da Constituição Federal de 1988, que sintetizou os anseios da nova democracia brasileira nas suas normas de caráter dirigente (em especial, naquelas sobre direitos fundamentais). Entretanto, nos primeiros anos da redemocratização, o corpo político nacional não conseguiu estabelecer um projeto capaz de impulsionar a aplicabilidade constitucional e o almejado estado de bem-estar social 
(welfare state). Ainda havia grande desconfiança em relação ao Poder Executivo em razão dos anos autoritários anteriores, e não havia qualquer unidade do Poder Legislativo em razão das divergências entre as multiplicidades de vontades dos diversos grupos que buscavam os seus papéis na nova ordem social. Nessa realidade metamórfica e disforme, coube aos juízes e aos tribunais assumirem o papel político protagonista e direcionarem a sua atuação para a promoção e a proteção das aspirações constitucionais. O Poder Judiciário tornou-se o novo pretenso agente externo, neutro e reativo apto a mediar conflitos entre os Três Poderes e manter o equilíbrio político brasileiro por meio dos mecanismos de controle de constitucionalidade.

Nos últimos trinta e um anos, juízes e tribunais (em especial, o Supremo Tribunal Federal) desempenharam o papel de guardiões constitucionais e decidiram controvérsias sobre direitos fundamentais que pavimentaram o percurso democrático brasileiro: união estável entre casais homoafetivos (BRASIL, 2011), aborto de fetos anencéfalos (BRASIL, 2012a), cotas raciais nas universidades públicas (BRASIL, 2012b) e criminalização da homofobia e transfobia (BRASIL, 2019) foram alguns dos temas já discutidos e resolvidos pelo STF. Todavia, apesar de esses julgamentos de caráter progressista terem apresentado importantes avanços na defesa dos direitos fundamentais e proteção dos grupos vulneráveis, a Corte Constitucional minou indiretamente a capacidade política do povo e dos seus representantes (Poderes Executivo e Legislativo) decidirem dilemas políticos relevantes.

Um problema ainda maior residiu no fato de que, em ocasiões paradigmáticas, o Supremo Tribunal Federal resolveu impasses políticos puros, que ultrapassaram a defesa de direitos fundamentais - e, até mesmo, os limites constitucionais - e definiram os pilares políticos brasileiros. O STF já avocou para si (e unicamente para si) a responsabilidade para determinar os ritos dos processos de impeachment tanto do expresidente Fernando Collor (BRASIL, 1993), quanto da ex-presidente Dilma Rousseff (BRASIL, 2015; BRASIL, 2016), para influenciar os rumos das eleições presidenciais nacionais de 2018 (BRASIL, 2018) e para obstar as nomeações ministeriais tanto de Luiz Inácio Lula da Silva (BRASIL, 2016) quanto de Alexandre Ramagem (BRASIL, 2020). Esses julgamentos (manifestações dos fenômenos da judicialização da política e do ativismo judicial) não apenas minaram a capacidade política do povo e dos seus representantes decidirem controvérsias políticas relevantes, mas também possibilitaram que o Poder Judiciário se agigantasse, aparelhasse o sistema político pátrio e utilizasse-o não em favor da vontade popular; mas sim da vontade particular de determinado indivíduo ou grupo de indivíduos.

Em outras palavras, no século XXI, os juízes e os tribunais - agentes pretensamente externos, neutros e reativos, mas verdadeiramente parciais e ativos acumularam poder ilimitado e passaram a ocupar um patamar político superior ao dos 
A ideia de equilíbrio político de Benjamin Constant no Constitucionalismo Brasileiro: Poder Judiciário como novo poder moderador?

Poderes Executivo e Legislativo, impuseram as suas vontades particulares sobre a vontade popular por meio do controle de constitucionalidade, ultrapassaram as suas amarras constitucionais e usurparam a soberania popular manifestada pela capacidade de definição política. O Poder Judiciário, então, sob o pretexto de mediar conflitos entre os Poderes e proteger direitos fundamentais, promoveu o desequilíbrio político e desempenhou função análoga à do Poder Moderador da Constituição Imperial de 1824.

Isso posto, este trabalho objetivará:

a) apresentar os principais pontos da teoria constitucional de limitação de poder de Benjamin Constant e relacioná-la com a materialização da Constituição Imperial de 1824 e do seu Poder Moderador, ainda tecendo críticas direcionadas tanto aos pressupostos de Constant, quanto à sua importação descontextualizada pelo constitucionalismo brasileiro;

b) analisar a atuação jurídico-política dos juízes e dos tribunais nacionais (em especial, do Supremo Tribunal Federal) e os fenômenos da judicialização da política e do ativismo judicial com base na teoria de limitação de poder de Constant como impropriamente recepcionada pelo pensamento constitucional pátrio.

Nesse sentido, este artigo adotará uma metodologia analítica, descritiva e avaliativa, valendo-se, prioritariamente, de revisão bibliográfica e investigação legislativa para desenvolver uma pesquisa verticalizada sobre a temática proposta. A abordagem sugerida será essencial para o estabelecimento de pressupostos teóricos essenciais, a interpretação dos dados e dos posicionamentos doutrinários analisados e a sintetização lógica das conclusões oferecidas. Versar-se-á, principalmente, sobre os postulados teóricos desenvolvidos por Benjamin Constant e Antonio Pimenta Bueno em seus livros Escritos de Politica e Direito Público Brasileiro (2005) e Análise da Constituição do Império (1958), respectivamente. Contudo, também, investigar-se-á, ainda que de forma periférica, obras fundamentais para o estudo sobre Direito Constitucional, Teoria Política e jurisdição constitucional.

Ainda é imprescindível ressaltar que as principais bases de dados digitais utilizadas para o desenvolvimento deste trabalho foram três: Google Acadêmico, Scielo e CAPES. Nelas, foram inseridas cinco chaves de pesquisa: "Poder Judiciário", "Poder Moderador", "Benjamin Constant", "Equilíbrio político" e "Judicialização da política".

Finalmente, comparar duas constituições contextualmente tão distintas quanto a Constituição Imperial de 1824 e a Constituição Federal de 1988 é um árduo desafio que, se não cumprido com esmero, cairá na armadilha do anacronismo. Os processos evolutivos de cada uma foram resultados de panoramas particulares: o Brasil de 1824 trilhava o processo de construção da sua identidade e visava à consolidar a unidade nacional por meio da autoridade do imperador; o Brasil de 1988, por sua vez, trilhava o 
processo de redemocratização e objetivava consolidar o estado de bem-estar social (welfare state) por meio da promoção e da proteção dos valores democráticos. Enquanto o projeto da Constituição Imperial serviu a interesses elitistas, escravocratas e nobiliárquicos, o projeto da Constituição da República serviu a interesses populares, liberais e humanistas. Ademais, destinada ao erro histórico mostra-se a tarefa de atribuir sentido idêntico de um elemento clássico a um elemento contemporâneo apenas porque ambos apresentam comum grafia. Por exemplo, não é possível afirmar que a ideia de soberania do século XIX compartilha o mesmo sentido semântico da ideia de soberania dos séculos XX e XXI. Ambas as opiniões são construtos diferenciados pelos momentos históricos que lhes atribuíram significado.

Por isso, este artigo não pretende traçar um comparativo direto entre a Constituição Imperial de 1824 e a Constituição Federal de 1988 ou entre os seus institutos que dispõem sobre as prerrogativas funcionais dos poderes políticos. $\mathrm{O}$ trabalho, na realidade, pretende contextualizar e compreender como a base ideológica da Constituição Imperial - alicerçada na teoria de controle de poder de Constant e essencial para a formação e o desenvolvimento do constitucionalismo brasileiro influenciou o processo interpretativo da Constituição Federal de 1988 e moldou a atuação dos juízes e dos tribunais como agentes pretensamente externos, neutros e reativos capazes de proteger os anseios democráticos e manter o equilíbrio político do Brasil do século XXI. Como defendia a dialética de Friedrich Hegel (170-1831), a realidade é um processo histórico (2014), e a adequada compreensão do panorama jurídico-político contemporâneo carece da adoção de uma perspectiva histórica.

\section{A IDEIA DE EQUILÍBRIO POLÍTICO DE BENJAMIN CONSTANT NO CONSTITUCIONALISMO BRASILEIRO}

Em razão do amálgama cultural, étnico e institucional que forma a sociedade brasileira, parece natural a conclusão de que o constitucionalismo nacional não possui identidade própria, sendo ele uma mera reprodução de instituições, leis, práticas e teorias estrangeiras. Entretanto, ainda que o constitucionalismo pátrio tenha sido (e ainda seja) consideravelmente influenciado pelo constitucionalismo alienígena, mostrase simplista afirmar que não existe inovação no pensamento constitucional brasileiro. Assim como ocorre em todas as outras realidades do mundo, as controvérsias econômicas, jurídicas, políticas e sociais do Brasil demandam soluções eminentemente regionais, e estas são derivadas de um longo processo histórico que contou com a importante mescla de elementos internos e externos. Assim, para a adequada análise do Poder Moderador, instaurado pela Constituição Imperial de 1824, faz-se necessária a apresentação dos principais pontos da teoria constitucional de limitação de poder de 
A ideia de equilíbrio político de Benjamin Constant no Constitucionalismo Brasileiro: Poder Judiciário como novo poder moderador?

Benjamin Constant, talvez principal fonte de inspiração para a concepção e o desenvolvimento do constitucionalismo nacional (ALVES, 2008).

Ainda que a teoria de Constant tenha sido elaborada como resposta a demandas próprias da sociedade francesa, ela foi baseada, em grande medida, na experiência inglesa. O mesmo aconteceu com a Constituição Imperial de 1824: ainda que o Poder Moderador tenha sido elaborado como resposta a demandas próprias da sociedade brasileira, ele foi baseado, em grande medida, na experiência francesa. Essa constatação em nada macula a relevância da discussão proposta, muito pelo contrário, destaca o caráter universal de algumas problemáticas e ressalta a importância da análise das realidades e das teorias políticas estrangeiras para a adequada compreensão das bases constitucionais nacionais e resolução das controvérsias econômicas, jurídicas, políticas e sociais comuns.

Serão tratados, incialmente, a teoria constitucional de Constant, dando um enfoque especial à sua ideia de Quinto Poder (ou Poder Real); posteriormente, o Quarto Poder (ou Poder Moderador), instituído pela Constituição Imperial de 1824; finalmente, as principais divergências entre os postulados sobre limitação de poder de Constant, bem como a instauração e a aplicação do Poder Moderador no Brasil do século XIX.

\subsection{O QUINTO PODER DE BENJAMIN CONSTANT (OU O PODER REAL)}

A teoria constitucional de limitação de poder de Benjamin Constant, concebida como resposta ao novo panorama sócio-político francês advindo dos movimentos revolucionários de 1789, não apenas fincou suas influências na França, mas também em diversas localidades do mundo que, inspiradas direta ou indiretamente pela experiência francesa, ajustaram os seus modelos políticos aos novos ares liberais dos séculos XVIII e XIX (ALVES, 2008). O Brasil foi um dos países inspirados pelos postulados do autor, e a materialização dessa influência se deu com a concepção e a elaboração da Constituição Imperial de 1824 e do seu Poder Moderador (LYNCH, 2005). Assim, é imprescindivel que este tópico discorra sobre as principais ideias de Constant relacionadas aos conceitos de soberania e Poder Real.

Constant rejeitava as teorias políticas de Hobbes e Rousseau: a primeira preceituava que a soberania era um poder ilimitado e perpétuo que emanava de um indivíduo ou assembleia de indivíduos (HOBBES, 1997); a segunda, por sua vez, preceituava que a soberania ilimitada deveria ser concentrada em e exercida pelo povo (ROUSSEAU, 2002). O autor francês defendia que essas ideias promoviam o abuso de poder e desequilíbrio político (CONSTANT, 2005, p. 11-13) e que o problema central dos pressupostos hobbesianos e rousseaunianos não consistia na possibilidade de acúmulo do poder soberano em um, poucos ou diversos indivíduos, mas sim na 
ausência de limites desse poder (CONSTANT, 2005, p. 7-17). Quase nada importava se a forma de governo adotada fosse uma monarquia, aristocracia ou democracia ${ }^{1}$, desde que a soberania fosse limitada por algo ou alguém. Para Constant, Hobbes e Rousseau erroneamente não se indispunham contra o uso da arma (soberania ilimitada), mas sim contra quem a manejava. Assim, os contratos sociais hobbesiano e rousseauniano, tantas vezes invocados em favor do bem e da justiça, mostravam-se os mais terríveis auxiliares de todos os gêneros de tirania e despotismo (CONSTANT, 2005, p. 10-11):

Quando se estabelece que a soberania do povo é ilimitada, cria-se e lança-se ao acaso na sociedade humana um grau de poder demasiado grande por si mesmo e que é um mal, quaisquer que sejam as mãos em que for posto. Confiem a um só, a vários, a todos, e encontrarão igualmente um mal. Vocês se voltarão contra os depositários desse poder e, conforme as circunstâncias, acusarão sucessivamente a monarquia, a aristocracia, a democracia, os governos mistos, o sistema representativo. Estarão errados, o que se deve acusar é o grau de força, e não os depositários dessa força (CONSTANT, 2005, p. 8).

Enquanto as teorias políticas de Hobbes e Rousseau buscavam garantir poder ilimitado a um único agente parcial e ativo (monarca e povo, respectivamente), a teoria de Constant buscava impor limites à soberania por meio de um poder mediador, concentrado em e exercido por um agente externo, neutro e reativo (CONSTANT, 2005, p. 12-13). A divergência entre as ideias apresentadas não residia nas possíveis formas de governo, mas sim na limitação do poder soberano. Tanto para Constant, quanto para Hobbes e Rousseau, em uma monarquia, a soberania era concentrada em e exercida por um único indivíduo; em uma aristocracia, por uma assembleia composta por poucos indivíduos; em uma democracia, por uma assembleia composta pela totalidade de indivíduos. Todavia, apenas o autor francês defendia que, nas três formas de governo elencadas, a soberania deveria ser restringida por um agente que mediasse os conflitos entre os poderes políticos, mantivesse o equilíbrio político e protegesse a unidade nacional (CONSTANT, 2005, p. 13-14).

Ainda assim, Constant reconhecia a problemática de como a limitação da soberania deveria ser realizada, não bastando a sua teorização. Mesmo que esse fosse um obstáculo real e de difícil solução, o autor propunha duas formas de impor restrições ao poder soberano: aceitação popular da ideia de que a soberania era limitada (proposta ideológica); apontamento de um agente neutro que combinasse os principais interesses

\footnotetext{
${ }^{1}$ Benjamin Constant, apesar de prever três formas de governo (monarquia, aristocracia e democracia), optava pela monarquia constitucional em razão de esta reunir o maior número de elementos capazes de limitar a soberania e manter o equilíbrio político por meio de um poder mediador concentrado em e exercido por um agente externo, neutro e reativo.
} 
A ideia de equilíbrio político de Benjamin Constant no Constitucionalismo Brasileiro: Poder Judiciário como novo poder moderador?

políticos das mais diversas classes sociais e que não participasse da constate disputa de poder (proposta institucional) (CONSTANT, 2005, p. 16-17). Assim, seria possível a limitação da soberania e a manutenção do equilíbrio político.

Isso posto, a teoria política de Constant pode, então, ser resumida a partir de duas máximas:

a) a soberania não era ilimitada, pois encontrava-se circunscrita em limites constitucionais definidos pela justiça e pelos direitos fundamentais;

b) e a restrição do poder soberano deveria ser realizada por um poder mediador concentrado em e exercido por um agente externo, neutro e reativo (CONSTANT, 2005, p. 15).

Em uma monarquia constitucional, Constant denominava esse poder mediador de "Poder Real" ou "Poder do Chefe de Estado". Enquanto os demais poderes políticos possuíam natureza parcial e ativa, o Poder Real tinha natureza neutra e reativa, pois concentrava-se em e era exercido pelo monarca, ocupante de uma posição política superior à dos demais agentes, o que lhe impedia de participar das disputas de poder. Caso algum dos poderes políticos ultrapassasse os limites constitucionais e direcionasse esforços para o benefício de um indivíduo ou grupo de indivíduos em detrimento da justiça ou dos direitos fundamentais, o chefe de Estado, por meio do exercício do Poder Real, remanejaria o panorama político e impediria a concretização dessa afronta à constituição. Por meio de uma atuação política incidental, resultante do seu caráter externo, neutro e reativo, o monarca era capaz de mediar os conflitos entre os poderes políticos. Assim, ainda que o chefe de Estado não participasse diretamente das disputas de poder, ele era capaz de garantir indiretamente a constitucionalidade desses embates. O Poder Real, então, servia para limitar a soberania e manter o equilíbrio político (CONSTANT, 2005, p. 18-19).

$\mathrm{O}$ verdadeiro interesse do monarca não era que um poder político derrubasse o outro, mas sim que todos os poderes se apoiassem para a promoção e a proteção dos anseios e dos valores constitucionais (CONSTANT, 2005, p. 19). O chefe de Estado, por ser um agente à parte e superior às diversidades de opiniões, pairaria acima das agitações humanas e não possuiria outro interesse que a manutenção da ordem e liberdade, deveria pôr fim a qualquer luta perigosa e restabelecer a harmonia entre os poderes políticos (CONSTANT, 2005, p. 20-22). Contudo, o monarca não poderia legislar, julgar, condenar, encarcerar, espoliar ou proscrever - atribuições dos demais poderes

2 O termo "Poder Real", provavelmente, foi optado em razão de Benjamin Constant versar, especificamente, sobre o ambiente político derivado da monarquia constitucional da França pósrevolução de 1789. Contudo, a lógica construída pelo autor pode ser empregada em uma aristocracia ou, até mesmo, em uma democracia, desde que haja um agente externo, neutro e reativo capaz de limitar o poder soberano e manter o equilíbrio político. 
políticos -, mas apenas "tirar o poder dos homens ou das assembleias que não saberiam detê-lo por muito tempo sem perigo." (CONSTANT, 2005, p. 23). Assim, o Poder Real não se concretizaria diretamente diante da constituição, mas proporcionaria a estabilidade política essencial para a materialização constitucional.

Constant ainda afirmava que existiam cinco poderes: Executivo (exercido pelos ministros); Representativo da Duração (exercido por uma assembleia hereditária); Representativo da Opinião Pública (exercido por uma assembleia eletiva); Judiciário (exercido pelos juízes e tribunais); e Poder Real (exercido pelo chefe de Estado). Os quatro primeiros poderes, parciais e ativos, podiam ser figurativamente comparados a engrenagens que compunham uma complexa máquina, que, eventualmente, travavam umas às outras e impediam o adequado funcionamento do sistema político; o Quinto Poder, neutro e reativo, por sua vez, podia ser figurativamente comparado a um lubrificante que destravava as engrenagens quando operavam de forma inesperada e prejudicial e retomava o adequado funcionamento do sistema político (CONSTANT, 2005, p. 19-20). O chefe de Estado, então, ao constatar extrapolação dos limites constitucionais ou conflito político entre agentes dos demais poderes, recorreria ao Poder Real e restauraria o equilíbrio político.

Finalmente, Constant alertava que o Poder Real não poderia ser concentrado em quem já concentrasse qualquer um dos outros poderes políticos. Como o monarca deveria ser externo, neutro e reativo, ao mediar um conflito político entre dois ou mais poderes, aquele não poderia conceder preferências para nenhum destes, o que certamente ocorreria caso houvesse confusão entre as figuras concentradoras do Poder Real e de qualquer outro poder (CONSTANT, 2005, p. 19-20). As prerrogativas de todos os poderes - assim como os seus limites constitucionais - deveriam ser bem definidas para que fosse possível a limitação da soberania: Executivo concretiza as leis; Legislativo cria as leis; Judiciário aplica as leis em casos particulares; Real mantém o equilíbrio entre os demais poderes (CONSTANT, 2005, p. 19-20). O Quinto Poder é, então, a "obra-prima da organização política” (CONSTANT, 2005, p. 22).

Por isso, a limitação da soberania ocorreria de forma mais adequada em uma monarquia constitucional se comparada a uma república. Naquela, o monarca seria dotado de natureza inviolável e irresponsável e, consequentemente, não participaria ativamente dos embates políticos; nesta, por sua vez, ele, assim como todos os outros agentes, seria dotado de natureza violável e responsável e, consequentemente, participaria ativamente dos embates políticos (CONSTANT, 2005, p. 27-30). A neutralidade do Chefe de Estado impediria concentração de poder ilimitado em um indivíduo ou grupo de indivíduos e manteria o equilíbrio político.

Visto isso, o que se deixa entender é que a teoria constitucional de limitação de poder de Constant reside no ponto em que o autor busca combater a ideia de soberania 
A ideia de equilíbrio político de Benjamin Constant no Constitucionalismo Brasileiro: Poder Judiciário como novo poder moderador?

ilimitada com um poder igualmente ilimitado. Constant jamais estabelece parâmetros claros e racionais que restrinjam a atuação do chefe do Estado no exercício do Poder Real, confiando cegamente que o rei ou imperador, por já ter a sua posição política preservada pelo critério hereditário, não se utilizará do Poder Real para influenciar e, até mesmo, controlar ativamente os demais poderes políticos. Em termos práticos, a proposta do autor, potencialmente, resulta na instauração de um governo absolutista "velado", no qual o chefe de Estado, por meio do exercício do Poder Real, resolve, ilimitadamente, qualquer questão política a partir do suposto argumento de manutenção do equilíbrio entre os demais poderes políticos.

A instituição política externa, neutra e reativa que modera os conflitos políticos e mantém o equilíbrio social, na realidade, jamais existiu (ao menos, no caso brasileiro). Como preleciona Aristóteles (2019), "o homem é um animal político", e os seus anseios políticos ditam, direta ou indiretamente, todas as suas ações. Dessa forma, o ponto basilar que tenta sustentar a teoria de Constant se demonstra frágil, e a ideia de Poder Real como poder mediador (ou moderador) não é capaz de promover a unidade nacional e o equilíbrio social pretendidos pelo autor.

\subsection{O QUARTO PODER DA CONSTITUIÇÃO IMPERIAL DE 1824 (OU O PODER MODERADOR)}

A transição do Brasil Colonial para o Brasil Imperial deveria ter sido "um desquite amigável entre os reinos unidos. Não há, porém, desquite perfeitamente amigável: precedem-no sempre incompatibilidades, rusgas e desavenças." (LIMA, 1997, p. 19). A tensão política entre Portugal e França advinda do Bloqueio Continental contra o Reino Unido Britânico resultou na invasão napoleônica à Lisboa e na transferência da corte portuguesa para o Brasil em 1808. A permanência da família real no País remodelou a sociedade brasileira ${ }^{3}$ e possibilitou a ascensão política nacional ao ponto de o Brasil assumir a condição de Reino Unido de Portugal, Brasil e Algarves em 1815. No final da década, despertou o espírito constituinte e emancipatório pátrio, e, temendo perder o seu principal aliado, Portugal instituiu as Cortes Constituintes Portuguesas, cuja suposta finalidade era conceber uma constituição liberal comum de todo o Reino Unido. Entretanto, os embates discursivos entre deputados brasileiros e lusitanos durante as sessões constituintes de 1821 escancararam os propósitos recolonizadores do projeto constituinte português, e o País, visando à consolidação da

\footnotetext{
${ }^{3}$ Abertura dos portos, criação da Imprensa Régia, fundação do Banco do Brasil, inauguração da Biblioteca Nacional em 1808 e instauração da Academia Real Militar em 1810 são alguns dos marcos que representaram o desenvolvimento social brasileiro após a vinda da Corte portuguesa para o País. Cf. Lima (1996).
} 
sua autonomia, manutenção do equilíbrio político e proteção da unidade nacional, deu início ao seu próprio projeto constituinte cuja materialização se deu com a independência nacional em 1822 e outorga da Constituição Imperial de 1824 (LIMA, 1997).

As ideias de equilíbrio político e unidade nacional foram postas à prova nos processos de independência e constitucionalização pátrios, uma vez que a almejada vontade geral deu lugar às vontades particulares manifestadas pelos diversos projetos políticos fundadores coordenados por grupos conflitantes. Cada um buscou impor os seus anseios básicos e as suas demandas fundamentais sem um aberto diálogo institucional capaz de garantir a legitimidade desses pleitos. $O$ setor conservador tentou manter algumas das bases políticas coloniais; o setor progressista, por sua vez, tentou extingui-las (LIMA, 1997). A complexidade do panorama brasileiro é evidente quando se analisa o caráter dicotômico da independência e da constitucionalização nacionais: processos que combinaram elementos identitários tanto de ruptura quanto de continuidade (PIMENTA, 2009). A realidade pátria foi sintetizada no discurso de José Bonifácio na Assembleia Constituinte Brasileira de 1823:

Eu não acho nas palavras do Imperador senão nossas próprias expressões e a vontade geral do leal povo do Brasil. Que quer esse povo? E para que tem trabalhado até agora tanto o governo? Para centralizar a união e prevenir as desordens que procedem de princípios revoltosos anarquia. O povo do Brasil, Sr. Presidente, quer uma constituição, mas não quer demagogia e anarquia [...]. Que quadro nos apresenta a desgraçada América! Há 14 anos que se dilaceram os povos, que, tendo saído de um governo monárquico, pretendem estabelecer uma licenciosa liberdade; e depois de terem nadado em sangue, não são mais que vítimas da desordem, da pobreza e da miséria [...]. Vimos os horrores da França; as suas constituições apenas feitas, logo destruídas, e por fim um Bourbon, que os franceses tinham excluído do trono e até execrado, trazer-lhes a paz e a concórdia! (BRASIL, 1823, p. 53).

Nesse contexto, a outorga da Constituição Imperial de 1824 propôs-se a dois objetivos principais: erguimento e solidificação dos pilares que serviriam como sustentáculos da monarquia constitucional brasileira; e estabelecimento de um projeto centralizado que manteria o equilíbrio político e protegeria a unidade nacional do Brasil independente (BUENO, 1958). Para mediar a grande diversidade de projetos políticos fundadores encabeçados por grupos, muitas vezes, antagônicos, a Constituição Imperial instaurou o Poder Moderador: capacidade de conciliar os conflitos entre os três outros poderes políticos concentrada em e exercida pelo imperador, agente pretensamente externo, neutro e reativo ${ }^{4}$ (ALVES, 2008, p. 67-70).

\footnotetext{
4 “Art. 98. O Poder Moderador é a chave de toda a organisação Política, e é delegado privativamente ao Imperador, como Chefe Supremo da Nação, e seu Primeiro Representante, para que incessantemente
} 
A ideia de equilíbrio político de Benjamin Constant no Constitucionalismo Brasileiro: Poder Judiciário como novo poder moderador?

Eis o epicentro de convergência entre as bases do constitucionalismo brasileiro e a teoria constitucional de limitação de poder de Benjamin Constant: visando à manutenção do equilíbrio político e à proteção da unidade nacional, a Constituição Imperial de 1824 instituiu o Poder Moderador, chave de toda a organização política. Assim como o Poder Real de Constant, o Poder Moderador da Constituição Imperial, supostamente adotando uma posição de neutralidade, desempenharia um papel conciliatório e mediaria os conflitos entre os outros poderes políticos por meio da observância dos limites constitucionais.

Além do Poder Moderador, mais inovadora contribuição da Constituição Imperial de 1824, esta reconheceu outros três poderes políticos ${ }^{5}$ : Executivo (concentrado em e exercido pelo imperador) ${ }^{6}$; Legislativo (concentrado em e exercido pela Assembleia Geral) ${ }^{7}$; e Judiciário (concentrado em e exercido pelos juízes e jurados) ${ }^{8}$. Ademais, definiu a soberania nacional ${ }^{9}$ e determinou a sua delegação para o imperador e a Assembleia Geral ${ }^{10}$, garantindo paridade formal entre o Executivo/Moderador e o Legislativo. Em tese, o poder soberano não se acumulava no monarca, que poderia utilizá-lo para agigantar a Coroa e coibir os avanços liberais; também não se acumulava no povo, que poderia utilizá-lo para solapar as tradições monárquicas e instaurar o anarquismo; acumulava-se na nação, que delegaria a concretização do poder soberano para o imperador e a Assembleia Geral tomando como base os limites constitucionais e a vontade geral (BUENO, 1958).

A concepção de Poder Real, como preceituada por Constant, foi incorporada ainda que de forma descontextualizada - pelo constitucionalismo brasileiro e serviu como um dos institutos essenciais para a mediação dos diversos embates políticos entre indivíduos ou grupos de indivíduos que buscavam concretizar seus projetos políticos fundadores do Brasil independente. $O$ exercício do Poder Moderador ${ }^{11}$ facilitou o

vele sobre a manutenção da independencia, equilibrio, e harmonia dos mais Poderes Politicos." (BRASIL, 1824, online).

5 “Art. 10. Os Poderes Políticos reconhecidos pela Constituição do Império do Brasil são quatro: o Poder Legislativo, o Poder Moderador, o Poder Executivo, e o Poder Judicial." (BRASIL, 1824, online).

6 "Art. 102. O Imperador é o Chefe do Poder Executivo, e o exercita pelos seus Ministros de Estado." (BRASIL, 1824, online).

7 "Art. 13. O Poder Legislativo é delegado à Assembleia Geral com a Sanção do Imperador." (BRASIL, 1824, online).

8 "Art. 151. O Poder Judicial independente, e será composto de Juízes e jurados, os quaes terão logar assim no Cível, como no Crime nos casos, e pelo modo, que os Códigos determinarem." (BRASIL, 1824, online).

9 “Art. 12. Todos estes Poderes no Império do Brasil são delegações da Nação.” (BRASIL, 1824, online).

10 "Art. 11. Os Representantes da Nação Brasileira são o Imperador, e a Assembleia Geral." (BRASIL, 1824, online).

11“Art. 101. O Imperador exerce o Poder Moderador: I. Nomeando os Senadores, na forma do art. 43.

II. Convocando a Assembleia Geral extraordinariamente nos intervalos das Sessões, quando assim o 
manejo das variadas vontades e obstaculizou a insurgência de um movimento político de verdadeira ruptura a partir do processo de independência. Quando algum poder político excedia as suas competências ou ultrapassava os limites constitucionais, supostamente o imperador remanejava o panorama político do País em busca da manutenção do equilíbrio político e da proteção da unidade nacional (BUENO, 1958).

Todavia, ainda que o exercício do Poder Moderador tenha resultado, de alguma forma, na manutenção do equilíbrio político e na proteção da unidade nacional do Brasil independente, ambas essas conquistas foram parciais, imperfeitas. Ao longo do século XIX (em especial, do Período Regencial), o caráter fragmentário da sociedade brasileira manifestou-se pela eclosão de diversos movimentos bélicos contra a Coroa: Confederação do Equador (1824); Noite das Garrafadas (1831); Revolta dos Malês (1835); Guerra dos Cabanos (1835-1840); Guerra dos Farrapos (1835-1845); Sabinada (1837-1838); Balaiada (1838-1841); e Guerra dos Maribondos (1851-1852). Variadas foram as particularidades de cada uma dessas insurgências, mas, direta ou indiretamente, todas compartilharam um elemento: irresignação contra o modelo político instituído pela Constituição Imperial de 1824.

Ora, se a monarquia constitucional brasileira visava à manutenção do equilíbrio político e à proteção da unidade nacional, por que ele foi combatido por diversos grupos políticos que, ao longo do século XIX, perseguiam esses mesmos objetivos? A resposta é a seguinte: na realidade, o equilíbrio político e a unidade nacional almejados pela Constituição Imperial de 1824 serviam não ao bem comum, mas sim à consolidação do poder ilimitado da Coroa. O Poder Moderador, sustentáculo de toda a organização política pátria, era "a chave mestra da opressão da nação brasileira e o garrote mais forte da liberdade dos povos." (CANECA, 1976, p. 100), e os discursos liberais consistiam em subterfúgios retóricos para a legitimação de uma monarquia absolutista velada (CANECA, 1976). Os movimentos bélicos contra a Coroa foram então insurgências não em objeção ao equilíbrio político ou à unidade nacional, mas sim ao poder ilimitado do imperador e às suas consequências perante o sistema político brasileiro.

Apesar de o texto liberal da Constituição Imperial de 1824 prever a separação e a

pede o bem do Império. III. Sancionando os Decretos e as Resoluções da Assembleia Geral, para que tenham força de Lei: Art. 62. IV. Aprovando e suspendendo interinamente as Resoluções dos Conselhos Provinciais: arts. 86 e 87. V. Prorrogando ou adiando a Assembleia Geral, e dissolvendo a Câmara dos Deputados, nos casos, em que o exigir a salvação do Estado; convocando imediatamente outra, que a substitua. VI. Nomeando e demitindo livremente os Ministros de Estado. VII. Suspendendo os Magistrados nos casos do Art. 154. VIII. Perdoando e moderando as penas impostas e os réus condenados por Sentença. IX. Concedendo Amnistia em caso urgente, e que assim aconselhem a humanidade, e bem do Estado." (BRASIL, 1824, online). 
A ideia de equilíbrio político de Benjamin Constant no Constitucionalismo Brasileiro: Poder Judiciário como novo poder moderador?

harmonia dos poderes políticos ${ }^{12}$, a soberania nacional e a equiparação entre o Executivo/Moderador e Legislativo, na prática, o Poder Moderador instituiu a concentração de poderes políticos, a soberania imperial e a usurpação dos demais poderes pelo Executivo/Moderador. O sistema político adotado pelo Brasil independente, formalmente, era uma monarquia constitucional na qual o imperador se mostrava limitado pelas amarras constitucionais, mas, materialmente, era uma monarquia absolutista na qual o imperador se desprendia de qualquer amarra constitucional por meio do exercício do Poder Moderador. A ideia de limitação da soberania de Constante não passou de uma ilusão liberal (CANECA, 1976).

Dessa forma, diversas são as críticas que podem ser direcionadas ao Poder Moderador da Constituição de 1824. A proposta constitucional do Brasil Imperial contrariava as próprias raízes, pois ia de encontro à teoria constitucional de Constant. Um dos pontos basilares da proposta do autor era o de que o poder real (equivalente ao Poder Moderador) deveria ser exercido por uma instituição política alheia a qualquer dos demais poderes e, consequentemente, às disputas políticas inerentes a eles. Entretanto, a Constituição de 1824 concentrou o Poder Moderador na figura do imperador, chefe do Poder Executivo. Isso permitiu que o imperador recorresse ao aparato institucional que lhe era disponível não para mediar os anseios dos poderes políticos do Brasil, mas sim para sobrepor as vontades do Poder Executivo sobre os demais.

$\mathrm{Na}$ realidade, as prerrogativas do Poder Moderador não visavam, prioritariamente, à ponderação dos conflitos políticos e à manutenção do equilíbrio e da unidade política, mas sim à imposição da supremacia do imperador. O imperador podia convocar os senadores e os ministros de forma livre, prorrogar a Assembleia Geral e suspender magistrados, ou seja, podia aparelhar todo o sistema político para que este funcionasse de acordo com os seus próprios interesses. A separação dos poderes de nada servia, pois, no final das contas, o Poder Moderador (em conjunto ao Executivo) possuía uma natureza ilimitada e agia ativamente para promover as vontades próprias. $O$ próprio Pimenta Bueno reconheceu que o Poder Moderador era o mais ativo dentre os poderes políticos (BONAVIDES, 1978).

A Constituição de 1824 utilizou os pressupostos de Constant apenas para legitimar um aparelhamento estatal capaz de consolidar e perpetuar o poder do imperador. Com base no pretenso argumento de promoção da unidade nacional e do equilíbrio político no Brasil, o Poder Moderador foi apto a subordinar todos à vontade de apenas um. A limitação do poder soberano proposta por Constant jamais ocorreu no

\footnotetext{
12 "Art. 9. A Divisão e a harmonia dos Poderes Políticos é o princípio conservador dos Direitos dos Cidadãos, e o mais seguro meio de fazer efetivas as garantias que a Constituição oferece.” (BRASIL, 1824, online).
} 
Brasil, e o Quarto Poder da Constituição de 1824 possibilitou, principalmente, a limitação da participação política popular.

Ainda assim, o pensamento de Benjamin Constant e a Constituição de 1824 exercem grande influência nas bases políticas que sustentam a sociedade brasileira até a atualidade. Uma dessas principais inspirações parece ser a ideia de necessidade de uma instituição que mantenha o equilíbrio entre os diversos setores políticos e evite a quebra da unidade nacional.

\section{PODER JUDICIÁRIO COMO NOVO PODER MODERADOR}

Ao longo dos últimos anos (em especial, de 1988 à contemporaneidade), o Poder Judiciário ganhou cada vez mais destaque na resolução de controvérsias morais e políticas que definiram os rumos democráticos trilhados pelo Brasil (VIANNA, 1997). O movimento neoconstitucionalista, que garantiu status normativo aos dispositivos constitucionais e possibilitou uma ativa atuação hermenêutica dos juízes e dos tribunais sobre a Constituição Federal de 1988, viabilizou que tanto dilemas sobre direitos fundamentais quanto impasses políticos puros fossem decididos não pelas instituições democráticas por excelência, como a Presidência da República e o Congresso Nacional, mas sim pelo Poder Judiciário (em especial, pelo Supremo Tribunal Federal), pretenso agente externo, neutro e reativo capaz de mediar conflitos entre os poderes políticos e manter o equilíbrio político. Assim, o povo e os seus representantes atuaram como meros observadores e passaram a ser coadjuvantes da sua própria história.

Essa inflação institucional do Poder Judiciário desequilibrou a balança dos três poderes e possibilitou a consolidação de dois fenômenos que ditam o caminho político traçado pela sociedade brasileira: o ativismo judicial e a judicialização da política (LIMA, 2003, p. 199-261). Por isso, a discussão sobre esses fenômenos é imprescindível para a adequada compreensão sobre a atuação jurisdicional no Brasil contemporâneo.

Serão levantados aqui dois aspectos importantes sobre os fenômenos do ativismo judicial e da judicialização da política, apresentando os seus conceitos e as suas principais implicações no cenário jurídico-político nacional após a redemocratização, e sobre a atuação política do Poder Judiciário sob uma perspectiva histórico-sistemática, traçando paralelos entre o papel político desempenhado pelos juízes e pelos tribunais e o Poder Moderador da Constituição Imperial de 1824.

\subsection{O ATIVISMO JUDICIAL E A JUDICIALIZAÇÃO DA POLÍTICA NO BRASIL REDEMOCRATIZADO}

Embora o ativismo judicial e a judicialização da política sejam fenômenos 
A ideia de equilíbrio político de Benjamin Constant no Constitucionalismo Brasileiro: Poder Judiciário como novo poder moderador?

conexos [Barroso (2012, p. 28) chama-os de "primos"], faz-se necessário estabelecer a distinção entre ambos para uma adequada análise da atuação jurisdicional no Brasil (em especial, a do Supremo Tribunal Federal).

A definição de ativismo judicial, em razão da alta complexidade do tema, não é consenso na academia ou jurisprudência brasileira (na realidade, não o é em lugar algum do mundo ocidental). Barroso define ativismo judicial como a ampla e a intensa interferência do Poder Judiciário em questões não disciplinadas pelo texto constitucional (BARROSO, 2012, p. 23-32); Antoine Garapon, por outro lado, define esse fenômeno como a interferência do Poder Judiciário sobre dilemas políticos com base no desejo do juiz para a conservação ou a transformação de determinada posição social (GARAPON, 1998). Ainda assim, independentemente da definição adotada, como prelecionam Lepper, Streck e Tassinari (2015, p. 51-61), há um parcial consenso doutrinário de que o ativismo judicial está intimamente vinculado a duas ideias: vontade do juiz e ultrapassagem do texto normativo. Assim, este artigo propõe o ativismo judicial como a atuação do Poder Judiciário que, com base na vontade dos juízes e dos tribunais, ultrapassa as barreiras semânticas impostas pelo texto normativo.

Exemplificando o fenômeno acima, é possível citar a decisão do Supremo Tribunal Federal referente à Ação Direta de Inconstitucionalidade 4.277/2011, na qual o STF reconheceu a constitucionalidade da união estável entre casais homoafetivos (BRASIL, 2011). Em sua argumentação, a Corte Constitucional defendeu uma interpretação extensiva do artigo 226 da Constituição de 1988 e uma interpretação conforme a Constituição do artigo 1.723 do Código Civil ${ }^{13}$ (BRASIL, 2002), elastecendo os sentidos dos termos "família", "homem" e "mulher" para corrigir uma injustiça histórica com a comunidade LGBTQ da sociedade brasileira. Assim, o Supremo Tribunal Federal, tomando como base apenas a vontade dos seus ministros (a decisão foi unânime) de promover uma transformação social pela via judicial, ultrapassou os limites semânticos impostos pelas próprias normas constitucional e infraconstitucional, no que pese a inegável justeza do teor da decisão em favor desse segmento social reconhecidamente marginalizado há décadas na sociedade brasileira.

Assim como no caso do ativismo judicial, não há uma definição pacífica da judicialização da política na doutrina nacional ou internacional. Nessa perspectiva, Barroso delimita judicialização da política (ou judicialização da vida) como a resolução de controvérsias políticas pelo Poder Judiciário, não pelas instâncias tradicionais: os Poderes Executivo e Legislativo. Entretanto, diferentemente do ativismo judicial, a judicialização da política independe da vontade de qualquer juiz ou tribunal

13 “Art. 1.723. É reconhecida como entidade familiar a união estável entre o homem e a mulher, configurada na convivência pública, contínua e duradoura e estabelecida com o objetivo de constituição de família." (BRASIL, 2002, online). 
(BARROSO, 2012, p. 24-28). Esse fenômeno é um fato natural decorrente do modelo constitucional brasileiro adotado, não um exercício deliberativo de vontade do Poder Judiciário (BARROSO, 2012, p. 28).

Ainda que a conceituação de Barroso de judicialização da política seja, possivelmente, a mais popular entre a doutrina e a jurisprudência nacionais, este artigo adotará outra definição, mais completa e mais bem formulada: a de Ran Hirschl (2006, p. 721-753). De acordo com o referido autor, judicialização da política consiste na interferência de juízes e tribunais sobre impasses morais e políticos, e esse fenômeno é subdividido em três faces: a primeira (judicialização orgânica) manifesta-se pela disseminação de discursos, jargões, mandamentos e procedimentos jurídicos na esfera política e nos fóruns decisórios dos impasses da vida cotidiana (HIRSCHL, 2006, p. 723); a segunda (judicialização vinda de baixo) manifesta-se pela expansão de competência de juízes e tribunais para a definição de políticas públicas por meio do uso dos instrumentos jurídicos de proteção dos direitos fundamentais (HIRSCHL, 2006, p. 724); a terceira (judicialização da megapolítica) manifesta-se pelo julgamento, por juízes e tribunais, de controvérsias políticas centrais que definem e dividem comunidades inteiras. É a interferência do Poder Judiciário sobre dilemas políticos nucleares que vão além da defesa dos direitos fundamentais e definem a razão de ser - raison d'être - das sociedades (HIRSCHL, 2006, p. 727).

É possível citar a decisão do Supremo Tribunal Federal referente ao Habeas Corpus 152.752, na qual o STF reconheceu a constitucionalidade da prisão do réu antes do trânsito em julgado do processo penal e, consequentemente, definiu uma política pública por meio do uso do controle de constitucionalidade, um instrumento jurídico de proteção dos direitos fundamentais (BRASIL, 2018, online). Em sua argumentação, o Supremo Tribunal Federal discutiu os limites do princípio da presunção de inocência e, por fim, defendeu uma interpretação extensiva do inciso LVII do artigo 5o da Constituição de $1988^{14}$, visando ao combate do problema da impunidade no Brasil. Nesse julgamento, o Supremo Tribunal Federal direcionou a maior parte do seu esforço retórico para o debate de natureza jurídica, mas o seu objetivo principal era político: a suposta luta contra a impunidade. Assim, buscando solucionar uma questão política, o STF revestiu a sua vontade política de verdade científica e, dentre as possibilidades interpretativas oferecidas pelo inciso LVII do artigo $5^{\circ}$ da Constituição, afirmou que apenas uma delas levava à decisão correta e justa: a que relativizava o princípio da presunção de inocência. $O$ ministro Luís Roberto Barroso, por exemplo, afirmou

14 “Art. 5. Todos são iguais perante a lei, sem distinção de qualquer natureza, garantindo-se aos brasileiros e aos estrangeiros residentes no País a inviolabilidade do direito à vida, à liberdade, à igualdade, à segurança e à propriedade, nos termos seguintes: LVII - ninguém será considerado culpado até o trânsito em julgado de sentença penal condenatória;" (BRASIL, 1988, online). 
A ideia de equilíbrio político de Benjamin Constant no Constitucionalismo Brasileiro: Poder Judiciário como novo poder moderador?

expressamente que interpretaria a norma constitucional de uma forma correta e justa ${ }^{15}$.

Parece possível concluir que a atuação política do Supremo Tribunal Federal ultrapassou os limites jurídicos tipicamente impostos pela Constituição Federal de 1988 e adentrou na seara política da sociedade brasileira durante os últimos trinta e um anos. A necessidade imposta pelo Poder Judiciário de promover a concretização dos direitos e das garantias fundamentais e de instaurar um estado de bem-estar nacional possibilitou que juízes e tribunais se valessem do aparato institucional judicial para promover não especificamente o bem-comum, mas também as suas vontades pessoais. Assim, o pacto democrático, essencial para a manutenção da estrutura política brasileira, foi fragilizado, e o cumprimento das promessas constitucionais encontra-se cada vez mais distante e improvável (BELO; BERCOVICI; LIMA, 2018).

\subsection{O QUARTO PODER DA CONSTITUIÇÃO FEDERAL DE 1988 (OU O PODER ANÁLOGO)}

A atuação política dos juízes e dos tribunais é justificada pela suposta necessidade de apaziguamento social e de restauração do equilíbrio político perdido em razão do mau funcionamento das instituições públicas, ou seja, o Poder Judiciário, atualmente, exerce um papel moderador perante a realidade política nacional.

Caso haja qualquer controvérsia advinda dos Poderes Executivo ou Legislativo, o Poder Judiciário, por meio do instrumento de revisão constitucional, mediará a situação e imporá uma solução ao caso concreto. Essa forma de agir se assemelha bastante às prerrogativas atribuídas ao Poder Moderador na Constituição Imperial de 1824. Assim como fazia o imperador, os juízes e os tribunais afirmam encontrar-se em um patamar acima dos demais agentes políticos, o que, suspostamente, garante-lhes uma neutralidade ilusória.

No Brasil Império, buscava-se o controle e a limitação da soberania por meio da atuação do imperador, chefe dos Poderes Executivo e Moderador. Quando os demais poderes, em tese, ultrapassavam as suas prerrogativas e adentrava na seara de incidência que não lhes pertencia tipicamente, o Poder Moderador era invocado, e o imperador aparelhava as instituições políticas para que funcionassem da forma que lhe agradasse. No Brasil redemocratizado, por sua vez, onde a soberania deveria ser exercida pelo povo e pelos seus representantes, o Poder Judiciário decide as principais controvérsias

\footnotetext{
15 "Portanto, com todas as vênias de quem pensa diferente, eu considero uma leitura equivocada da Constituição interpretar essas normas como julgado. Nenhuma interpretação jurídica que leve ao absurdo pode ser uma interpretação jurídica legítima e sustentável. Prefiro outra: interpretar de uma forma que conduza ao que é justo, correto e legítimo, significando que somente se pode prender alguém depois do trânsito em julgado."
} 
políticas e, consequentemente, impossibilita a real participação política popular. Os Poderes Executivo e Legislativo encontram-se inaptos de decidirem os rumos democráticos do País, e o povo passa a encontrar-se em um constante estado de imaturidade política. Os juízes e os tribunais, então, atuam como o superego de uma sociedade infantilizada, que não tem a capacidade de autogerência (MAUS, 2000, p. 183-202).

Ora, era exatamente isso que realizava o Poder Moderador no Brasil Império. Assim, de acordo com Pimenta Bueno, a nação brasileira possui um grande poder que não pode exercer por si mesma, devendo delegá-lo a uma instituição específica. No século XIX, essa instituição era a Coroa, representada pela figurada imperador; no século XXI, essa instituição é o Poder Judiciário, representado pelo Supremo Tribunal federal, autoproclamado guardião constitucional.

Dessa forma, os juízes e os tribunais, ao valerem-se das possibilidades jurídicas oferecidas pela Constituição de 1988 para promoverem a concretização das suas vontades políticas, repetem o processo já conhecido pela historiografia nacional semelhante àquele do imperador na aplicação do Poder Moderador. Na realidade, o Poder Judiciário apenas usa a pretensa justificativa de atuação ativa para a manutenção do equilíbrio político e da unidade nacional para consolidar cada vez mais o seu poder. O constitucionalismo brasileiro, moldado pela crença da necessidade de uma instituição que controle os anseios dos diversos agentes políticos, promoveu uma inflação institucional do Poder Judiciário capaz de estabelecê-lo como um órgão político de caráter ilimitado. Assim, pode-se afirmar que o Poder Judiciário é o novo Poder Moderador.

A ideia proposta por Constant de limitação da soberania e reestabelecimento do equilíbrio político foi incorporada no âmago do sistema político brasileiro a partir da independência. Desde então, não houve sequer um período histórico em que o poder soberano pudesse ser exercido de forma livre. A limitação do poder soberano por uma instituição não é nada mais do que a transferência velada da soberania de um ente legitimado para outro ente usurpador. O sentido do poder real de Constant, que se transformou em lógica do Poder Moderador, que se transformou em lógica do Poder Judiciário, não sustenta uma sociedade que pretende ser democrática e soberana. Faz-se, então, necessário que se construa politicamente a contenção do Poder Judiciário, seja pelos poderes representativos da soberania popular, seja pela própria soberania popular.

\section{CONCLUSÃO}

O presente artigo, a partir do estabelecimento dos seus pressupostos teóricos e do desenvolvimento da argumentação proposta, convergiu em seis conclusões principais. 
A ideia de equilíbrio político de Benjamin Constant no Constitucionalismo Brasileiro: Poder Judiciário como novo poder moderador?

Primeira: a teoria constitucional de Benjamin Constant exerceu grande influência não apenas na França do Século XIX, mas também em diversas outras localidades e em muitos outros períodos históricos. De acordo com o autor, a soberania não pode ser ilimitada e deve ser restringida pelo poder real (capacidade de moderar os conflitos travados entre os demais poderes), concentrado em uma instituição política externa, neutra e reativa. Na realidade francesa pós-revolução de 1789 , essa instituição consistiu na Coroa, representada pela figura do rei, que deveria utilizar-se do poder real para conter os Poderes Executivo, Legislativo e Judiciário caso eles ultrapassassem as suas prerrogativas típicas e, consequentemente, para garantir o equilíbrio político da França.

Segunda: a base do constitucionalismo brasileiro foi moldada a partir das ideias de Benjamin Constant. Assim, a Constituição Imperial de 1824, primeira do Brasil, dispôs que a soberania nacional deveria ser limitada pelo Poder Moderador (Quarto Poder), exercido pelo imperador, cujos objetivos primários são a mediação dos Poderes Executivo, Legislativo e Judiciário e também a manutenção do equilíbrio político, essencial para o fortalecimento da unidade nacional.

Terceira: faz-se necessário tecer duas críticas (um referente à teoria constitucional de Benjamin Constant; outra referente à tentativa de concretização dessa teoria pela Constituição Imperial de 1824). Em um momento inicial, Constant buscou combater um poder ilimitado (poder soberano) com outro poder igualmente ilimitado (Poder Real), uma vez que jamais estabeleceu qualquer parâmetro racional de restrição da atuação do chefe de Estado. Dessa forma, o resultado dos postulados do autor não é a contenção de um poder ilimitado, mas apenas a sua transferência de um depositário para outro. Posteriormente, a Constituição de 1824, apesar de tomar as ideias de Constant como base, deturpou-as, pois, contrariamente ao defendido pelo autor, então, o Poder Moderador concentrou-se não nas mãos de uma instituição externa e neutra, mas sim nas do imperador, agente político ativo e parcial que exerceu tanto o Poder Moderador quanto o Poder Executivo. Essas duas falhas apontadas possibilitam o aparelhamento das instituições políticas e a instauração de um poder ilimitado por quem detém o poder de mediação.

Quarta: a crescente atuação política dos juízes e dos tribunais (em especial, a partir da redemocratização brasileira) promoveu uma inflação institucional do Poder Judiciário e derivou em dois fenômenos que moldam as estruturas políticas nacionais: o ativismo judicial e a judicialização da política. Ao decidirem controvérsias políticas com base na necessidade de concretização dos direitos e das garantias fundamentais e também de promoção de um estado de bem-estar social, os juízes expandem, unilateralmente, as suas competências típicas, limitam a participação política do povo e dos seus representantes, verdadeiros soberanos, e fragilizam o pacto democrático brasileiro. 
Quinta: finalmente, as pretensas ideias de manutenção de um equilíbrio político e de necessidade de limitação do poder soberano - e, consequentemente, da participação política popular - possibilitou que os juízes e os tribunais agissem como supostos agentes externos e neutros e delimitassem os rumos políticos a serem seguidos pelo Brasil. Assim, o Poder Judiciário tornou-se virtualmente absoluto e passou a aparelhar as estruturas políticas nacionais para que elas servissem à sua vontade, ou seja, o Poder Judiciário tornou-se o novo Poder Moderador.

Sexta: a única solução para a limitação do Poder Judiciário não é a instituição de um novo poder mediador (como, possivelmente, proporia Benjamin Constant), mas sim a concretização do sistema de freios e contrapesos, bem como a promoção da participação política representativa e popular, a qual é a verdadeira soberania e o verdadeiro agente político capaz de traçar o percurso democrático da sociedade brasileira.

\section{REFERÊNCIAS}

ALVES, Cleber Francisco. A influência do pensamento liberal de Benjamin Constant na formação do Estado Imperial Brasileiro. Revista de Informação Legislativa, n. 180, p. 65-75, 2008.

ARISTÓTELES. Política. São Paulo: Edipro, 2019.

BARROSO, Luís Roberto. Judicialização, ativismo judicial e legitimidade democrática. [Syn]Thesis, Rio de Janeiro, v. 5, n. 1, p. 23-32, 2012.

BELLO, Enzo; BERCOVICI, Gilberto. LIMA, Martonio Mont'Alverne Barreto. O Fim das Ilusões Constitucionais de 1988? Revista Direito e Práxis, Rio de Janeiro, 2018. Ahead of print.

BONAVIDES, Paulo. Reflexões: Política e Direito. São Paulo: Forense, 1978.

BRASIL. Anais da Assembleia Constituinte Brasileira de 1823. Rio de Janeiro: Anais do Parlamento Brasileiro, 1823.

BRASIL. Constituição (1824). Constituição Política do Império do Brasil. Brasília, DF: Presidência da República, 1824. Disponível em: http://www.planalto.gov.br/ccivil_03/Constituicao/Constituicao24.htm. Acesso em: 2 jan. 2020.

BRASIL. Constituição da república federativa do Brasil de 1988. Brasília, DF: Presidência da República, 1988. Disponível em: http://www.planalto.gov.br/ccivil_03/constituicao/constituicao.htm. Acesso em: 2 jan. 
A ideia de equilíbrio político de Benjamin Constant no Constitucionalismo Brasileiro: Poder Judiciário como novo poder moderador?

2020.

BRASIL. Supremo Tribunal Federal. Mandado de Segurança 21.689. Brasília, DF, 16 dez. $1993 . \quad$ Disponível em: http://www.stf.jus.br/arquivo/cms/sobreStfConhecaStfJulgamentoHistorico/anexo/MS 21689.pdf. Acesso em: 2 jan. 2020.

BRASIL. Lei no 10.046, de 10 de janeiro de 2002. Institui o Código Civil. Brasília, DF: Presidência da República, 2002. Disponível em: http://www.planalto.gov.br/ccivil_03/leis/2002/110406.htm. Acesso em: 2 jan. 2020.

BRASIL. Supremo Tribunal Federal. Ação Direta de Inconstitucionalidade 4.277. Brasília, DF, 13 out. 2011. Disponível em: http://redir.stf.jus.br/paginadorpub/paginador.jsp?docTP=AC\&docID=628635. Acesso em: 2 jan. 2020.

BRASIL. Supremo Tribunal Federal. Arguição de Descumprimento de Preceito Fundamental 54. Brasília, DF, 12 abr. 2012a. Disponível em: http://portal.stf.jus.br/processos/detalhe.asp?incidente=2226954. Acesso em: 2 jan. 2020.

BRASIL. Supremo Tribunal Federal. Recurso Extraordinário 597.285. Brasília, DF, 9 maio 2012b. Disponível em: http://redir.stf.jus.br/paginadorpub/paginador.jsp?docTP=TP\&docID=5455998.

Acesso em: 2 jan. 2020.

BRASIL. Supremo Tribunal Federal. Arguição de Descumprimento de Preceito Fundamental 378. Brasília, DF, 17 dez. 2015. Disponível em: http://redir.stf.jus.br/paginadorpub/paginador.jsp?docTP=TP\&docID $=10444582$.

Acesso em: 2 jan. 2020.

BRASIL. Supremo Tribunal Federal. Ação Direta de Inconstitucionalidade 5.498. Brasília, DF, 14 abr. 2016. Disponível em: http://redir.stf.jus.br/paginadorpub/paginador.jsp?docTP=TP\&docID $=12872463$. Acesso em: 2 jan. 2020.

BRASIL. Supremo Tribunal Federal. Mandado de Segurança 34.070. Brasília, DF, 18 mar. 2016.2 Disponível em: https://www.stf.jus.br/arquivo/cms/noticiaNoticiaStf/anexo/ms34070.pdf. Acesso em: 2 jan. 2020.

BRASIL. Supremo Tribunal Federal. Habeas Corpus 152.752. Brasília, DF, 4 abr. 2018. Disponível em: http://portal.stf.jus.br/processos/downloadPeca.asp?id=314692762\&ext=.pdf. Acesso em: 2 jan. 2020. 
BRASIL. Supremo Tribunal Federal. Ação Direta de Inconstitucionalidade por Omissão 26. Brasília, DF, 20 fev. 2019. Disponível em: http://www.stf.jus.br/arquivo/cms/noticiaNoticiaStf/anexo/ADO26votoMCM.pdf. Acesso em: 2 jan. 2020.

BRASIL. Supremo Tribunal Federal. Mandado de Segurança 37.097. Brasília, DF, 29 abr. 2020. Disponível em: http://www.stf.jus.br/arquivo/cms/noticiaNoticiaStf/anexo/MSRamagem.pdf. Acesso em: 29 abr. 2020.

BUENO, José Antonio Pimenta Bueno. Direito Público Brasileiro e Análise da Constituição do Império. São Paulo: Livraria dos Advogados, 1958.

CANECA, Frei. Ensaios Políticos. Rio de Janeiro: Editora Documentário, 1976.

CONSTANT, Benjamin. Escritos de Política. São Paulo: Martins Fontes, 2005.

GARAPON, Antoine. O Guardador de Promessas. Justiça e Democracia. Lisboa: Instituto Piaget, 1998.

HEGEL, Friedrich. Fenomenologia do Espírito. Petrópolis: Editora Vozes, 2014.

HIRSCHL, Ran. The new constitutionalism and the judicialization of pure politics worldwide. Fordham Law Review, New York, v. 75, n. 2, p. 721-753, 2006.

HOBBES, Thomas. Leviatã: ou Matéria, Forma e Poder de um Estado Eclesiástico e Civil. São Paulo: Nova Cultural, 1997.

LEPPER, Adriano Obach; STRECK, Lenio Luiz; TASSINARI, Clarissa. O problema do ativismo judicial: uma análise do caso MS3326. Revista Brasileira de Políticas Públicas, Brasília, v. 5, p. 52-61, 2015.

LIMA, Manuel de Oliveira. Dom João VI no Brasil. Rio de Janeiro: Topbooks, 1996.

LIMA, Manuel de Oliveira. O Movimento da Independência: 1821-1822. São Paulo: Topbooks, 1997.

LIMA, Martonio Mont'Alverne Barreto. Jurisdição Constitucional: Um Problema da Teoria da Democracia Política. In: SOUZA NETO, Cláudio Pereira de; BERCOVICI, Gilberto; MORAES FILHO, José Filomeno de; LIMA, Martonio Mont'Alverne Barreto. Teoria da Constituição: Estudos sobre o Lugar da Política no Direito Constitucional. Rio de Janeiro: Lumen Juris, 2003. p. 199-261.

LYNCH, Christian Edward Cyril. O Discurso Político Monarquiano e a Recepção do Conceito de Poder Moderador no Brasil (1822-1824). DADOS, Rio de Janeiro, v. 48, n. 3, p. 611-654, 2005. 
A ideia de equilíbrio político de Benjamin Constant no Constitucionalismo Brasileiro: Poder Judiciário como novo poder moderador?

MAUS, Ingeborg. Judiciário como Superego da Sociedade: o papel da atividade jurisprudencial na "sociedade órfã". Novos Estudos CEBRAP, São Paulo, v. 58, p. 183202, 2000.

PIMENTA, João Paulo G. A independência do Brasil como uma revolução: História e atualidade de um tema clássico. História da Historiografia: International Journal of Theory and History of Historiography, Ouro Preto, v. 2, n. 3, p. 53-82, 2009.

ROUSSEAU, Jean Jacques. Do Contrato Social: ou Princípios de Direito Político. São Paulo: RT, 2002.

VIANNA, Luiz Werneck. Corpo e alma da magistratura brasileira. Rio de Janeiro: Revan, 1997.

\section{NOTA}

Optou-se pelo modelo de coautoria na elaboração deste artigo em razão tanto das contribuições específicas oferecidas por cada autor, quanto da síntese dialógica resultante do exercício de produção científica na sua forma colaborativa. $O$ autor Martonio Mont'Alverne Barreto Lima, além de exercer o papel de orientador geral do trabalho, desenvolveu pesquisa prioritariamente focada nas contribuições oferecidas por Benjamin Constant e José Antonio Pimenta Bueno para a formação do pensamento constitucional brasileiro; o autor Ítalo Reis Gonçalves, por sua vez, desenvolveu pesquisa prioritariamente focada nos fenômenos do ativismo judicial e da judicialização da política e em como ambos relacionam-se com os postulados teóricos de Constant e Bueno. Contudo, como já mencionado, o artigo foi desenvolvido de forma colaborativa, então as prerrogativas de cada coautor expandiram-se e imiscuíram-se na medida em que a complexidade do trabalho exigiu resultados que convergissem em sólida pesquisa científica sobre a temática proposta.

\section{Como citar este documento:}

LIMA, Martonio Mont'Alverne Barreto; GONÇALVES, Ítalo Reis. A ideia de equilíbrio político de Benjamin Constant no Constitucionalismo Brasileiro: Poder Judiciário como novo poder moderador?. Revista Opinião Jurídica, Fortaleza, v. 18, n, 29, p. 171 197, set./dez. 2020. 